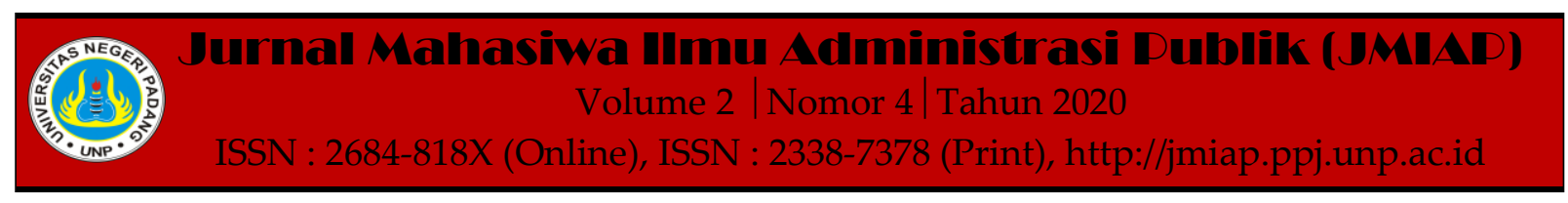

\title{
PENERAPAN PERATURAN WALIKOTA PADANG NOMOR 25 TAHUN 2016 TENTANG KAWASAN TANPA ROKOK DI SMP NEGERI 13 KOTA PADANG
}

\author{
Jayanti $^{1(a)}$, Nora Eka Putri ${ }^{2(b)}$ \\ ${ }^{1}$ Jurusan Ilmu Administrasi Negara, Universitas Negeri Padang \\ ${ }^{2}$ Jurusan Ilmu Administrasi Negara, Universitas Negeri Padang \\ a)jayantiry01@gmail.com, b)noraekaputri@fis.unp.ac.id
}

\begin{abstract}
This article aims to describe the Application of Padang Mayor Regulation Number 25 Year 2016 on Non-Smoking Areas in SMP Negeri 13 Padang City. Based on the regulation of the mayor of padang which includes non-smoking areas are Health Service Places, Teaching and Learning Process, Children Play, Worship, Public Transportation, Workplaces And other Public Places that have been determined. SMPN 13 is a place for teaching and learning. This research uses George C Edwar III Theory related to Communication, Resources, Disposition and Bureaucracy. This research uses descriptive qualitative method with Porposive Sampling informant selection technique. Data collection techniques are carried out with interviews, observations and documentation. The result obtained from research at SMPN 13 Padang city is the implementation of Padang Mayor Regulation No. 25 of 2016 on non-smoking areas.
\end{abstract}

Keywords : Place of Teaching and Learning Process, Regulations, Non-Smoking Area

Corresponding author. Email. jayantiry01@gmail.com

How to cite this article. Jayanti \& Putri, N. Eka. (2020). Penerapan Peraturan Walikota Padang Nomor 25 Tahun 2016 Tentang Kawasan Tanpa Rokok di SMP Negeri 13 Kota Padang. Jurnal Mahasiwa Ilmu Administrasi Publik (JMIAP) Jurusan Ilmu Administrasi Negara Fakultas Ilmu Sosial Universitas Negeri Padang, Volume 2 (4), Hal. 78-84.

http://jmiap.ppj.unp.ac.id

ISSN : 2684-818X (Online), ISSN : 2338-7378 (Print)

Copyright@2020. Published by Labor Jurusan Ilmu Administrasi Negara FIS UNP, Padang 


\section{PENDAHULUAN}

Implementasi ialah menyusun suatu kaitan (Lingkage) yang mempermudah maksud dari kebijakan agar bisa direalisasikan sebagai akses satu kegiatan pemerintah dimana media khusus yang sudah direncanakandan di jalankan sesuaiyang diinginkan dan sampai pada tujuan(Winarno, 2012, p. 149).

Merokok yaitu sebuah kebiasaan yang dapat memberikan dampak negative baik untuk para pelakunya maupun orang lain disekitarnya. Kebiasaan merokok sudah merata keseluruh anggota masyarakat di Indonesia yang cenderung memuncak. Tingginya pengguna rokok masyarakat Indonesia diyakini dapat meberikandampak yang buruk dan sangat luas, bukan hanya berdampak pada kesehatan, tetapi juga berkaitan dengan keadaan sosial, dan ekonomi masyarakat Indonesia.

Berlandaskan UUD 1945 Pasal $28 \mathrm{H}$ ayat (1) menyatakan setiap orang berhak hidup sejahtera lahir dan batin, memiliki tempat tinggal, memperoleh linkungan hidup yang sehat serta berhak memperoleh pelayanan kesehatan.

Undang-Undang RI Nomor 36 Tahun 2009 tentang kesehatan pada pasal 115 ayat 1,2. Peraturan Pemerintah (PP) No.109 tahun 2012 tentang penanganan bahan yang terdapat zat adaptif berupa tembakau untuk kesehatan.

Menteri kesehatan dan Menteri Dalam Negeri menetapkan pedoman (KTR). Menteri Kesehatan bertindak berkaitan dengan kesehatan yang disebabkan karenarokok, sementara itu Menteri Dalam Negeri menangani suatu yang berkaitan dengan pemerintah daerah, dalam merealisasikan kawasan tanpa rokok. Peraturan bersama Menteri Kesehatan dan Menteri Dalam Negeri Nomor 188 tahun 2011 dan Nomor 7 Tahun 2011 tentang pedoman pelaksanaan KTR.

Panduan kawasan tanpa rokok yang telah ditetapkan kementerian, setelah ituditetapkan aturandaerah yang secara hierarki Perundang-Undangan Pemerintah
Daerah terlibat selaku Implementor. Oleh karenanya pemerintah daerah kota Padang juga menerapkan Peraturan daerah kawasan tanpa rokok nomor 24 tahun 2012, yang dahulunya hanya mempunyai peraturan walikota dan dikuatkan dengan Peraturan Walikota Padang Nomor 25 tahun 2016.

Rokok merupakan suatu zat adaptif pembunuh paling berbahaya. Bahaya merokok pada remaja antara laindapat menumbuhkan kanker paru-paru, penyakit jantung diusia remaja. Melainkan dari itu juga berakibat pada kekeriputan area mata dan mulut.Kulit terlihat lebih tua ataudapat dikatakan penuaan dini.

\section{TINJAUAN PUSTAKA}

(Wahab.S, 2013, p. 133) mengemukakan bahwa Implementasi dianggap sebagai sistem pengoperasionalisasian atau pelaksanaan aktifitas yang sudah diatur dalam Undang-Undang dan jadi persetujuan bersama diantara berbagai pihak yang terkait, organisasi (Publik maupun privat) metode secara sinergis yang diarahkan untuk melaksanakan kebijakan kearah yang dikehendaki. Wahab berpendapat dengan cara seperti ini bertujuan agar perilaku dan pikiran segenap pihak yang terkaitdapat ditanggulangi serta terjaga pada koridornya.

Teori George C Edwar III berpandangan bahwa implementasi kebijakan dipengaruhi oleh empat variabel (Subarsono, 2011, pp. 90-92) yaitu:

a) Komunikasi, yaitu keberhasilan implementasi kebijakan mensyaratkan agar implementor mengetahui apa yang harusdilakukan, dimana yang menjadi tujuan dan sasaran kebijakan harus ditransmisikan kepada kelompok sasaran (target group), sehingga akan mengurangi distori implementasi.

b) Sumberdaya, meskipun isi kebijakan telah di komunikasikan secara jelas dan konsisten, tetapi apabila implementator kekurangan sumberdaya untuk melaksanakan, maka implementasi tidak akan berjalan efektif. Sumberdaya tersebut bisa dapat berwujud sumber daya manusia, misalnya kompetensi 
imlementator dan sumber daya finansial.

c) Disposisi, adalah watak dan karakteristik yang dimiliki oleh implementator, seperti komitmen, kejujuran, sifat demokratis. Apabila implementator memiliki disposisi yang baik, maka implementator tersebut dapat menjalankan kebijakan dengan baik seperti apa yang diinginkan oleh pembuat kebijakan. Ketika implementor memiliki sikap atau persepektif yang berbeda dengan pembuat kebijakan, maka proses implementasi kebijakan juga menjadi tidak efektif.

d) Struktur birokrasi, struktur organisasi yang mengimplementasikankebijakan memiliki pengaruh yang signifikan terhadap implementasi kebijakan. Aspek dari struktur organisasi adalah Standar Operating Procedure (SOP) dan fragmentasi.

\section{Kebijakan Publik}

Menurut Anderson dalam (Arenawati, 2014) kebijakan ialah perbuatan yang memiliki tujuan yang dilakukan seorang untuk menyelesaikan satu masalah, yang bertujuan untuk memenuhi kebutuhan dan kepentingan masyarakat.

Menururt Carl Federich (Dwiyanto, 2009, p. 18) kebijakan ialah suatu kegiatan yang di lakukan individu, kelompok atau pemerintah di suatu wilayah berkaitan dengan adanya kendala ketika mencari kesempatan untuk mencaai sasaran.

Menurut Hubermas dalam (Parson, 2001) publik ialah sebuah ruangan yang bebas dari campur tangan ekonomi, bisnis dan ruang yang mana memiliki pemisah yang jelas antara ruang umum dan rauang khusus.Selaku ruang yang melingkup dunia bisnis dan dimana lingkup kehidupan pribadi jauh lebih luas dari yang dimengerti dan di kembangkan.

George C. Edwar III dan Ira Sharkansky (Yusuf \& Switri, 2009) memaknai kebijakan publik yaitusatu perbuatan pemerintah berwujud strategi untuk mencapai sasaran. Kebijakan publik ialah tempat bergantung banyak pihak akan penyelesaian masalah publik secara praktis dan dapat diterima oleh beragam kelompok kepentingan yang teribat. Kebijakan publik juga perlu dikembangkan sebagai alat untuk mewujudkan perubahan di area publik dan dapat berubah lebih cepat dari yang di usahakan oleh kebijakan publik yang dahulunya.

Wiliam N.Dunn dalam (Pasolog, 2007, p. 39) memaknai kebijakan publik yaitu suatu rangkaian pilihan dan saling berhubungan, dilakukan instansi atau pemerintah, misalnya kesejahteraan masyarakat baik eilayah perdesaan dan perkotaan.Kebijakkan publik dapat dijelaskan sebagai rangkaian perbuatan yang di lakukan atau tidak oleh pemerintah, baik oleh satu orang maupun sekelompok orang untuk mencapai tujuan tertentu yang berorientaassi kepada kepentingaan masyarakat.

\section{Implementasi Kebijakan Publik}

Menurut Dunn (. et al., 2016)Implementasi kebijakan adalah pelaksana kontrol atas tindakan kebijakan selama periode waktu tertentu. Menurut Widodo (dalam Haerul dkk. 2016) menyatakan bahwa implementasi kebijakan adalah proses penerapan aturan yang belum jelaskedalam realita nyata. Jadi implementasi kebijakan ialah bentuk dari kebijakan yang sudah dilakukan dalam rentang waktu yang di tentukan.

(Indiahono: 2009) menjelaskan bahwa implementasi kebijakan menngacu pada kegiatan pelaksana kebijakan di dunia nyata, yang di laakukan oleh pemerintah maupun pihak yang telah di tentukan yang merupakan langkaah penting dari kebijakan tersebut.Langkah ini menyatakan apakah pemerintah telah menerapkan kebijakan dengan benar daan berhasil sebagaimana yang diinginkan.

\section{Teori Kendala (Teori of Constraints)}

Kamus Besar Bahasa Indonesia (2008:667) memaknai kendala sebagai 
suatu hambatan dengan keadaan memiliki batasan, hambatan dan halangan untuk mencapai tujuan. Dasar dari Teori of Constraints(TOC) yaitu setiap organisasi memiliki rintangan yang menghalangi sasaran kinerja (Performance) yang baik.

Kendala-kendala yang ada semestinya diidentifikasi dan diatur untuk mengubah kinerja.Apabila satu kendala sudah dipecahkan lalu kendala yang terjadi berikutnya dapat diidentifikasi dan diperbaharui.

\section{Konsep Pemerintah Daerah}

Pemerintah daerah adalah badan yang memiliki kekuasaan dan kewajiban untuk menangani pelayanan publik dan kewajiban untuk menangani pelayanan publik untuk semua melalui pemerintahan, sehingga masyarakat yang terkena dampak menerimanya pada saat dibutuhkan, sesuai dengan tuntutan yang di perintahkan. (Ndraha, 2003).

\section{Kawasan Tanpa Rokok}

KTR merupakan ruang/ arenaditetapkan tidak diperbolehkan untuk merokok, produksi, penjualan, iklan dan promosi produk tembakau. Tempat tertentu yang diperbolehkan untuk merokok yaitu ruang tertentu yang ada didalam kawasan tanpa rokok (KTR).Tujuan penetapan zona bebas asap rokok adalah melindungi masyarakat dari risiko gangguan kesehatan, terkait dengan paparan lingkungan terhadap asap rokok.

Penetapan kawasan bebas rokok sebaiknya dilakukan kisaran area fasilitas kesehatan, area proses belajar mengajar, area bermain anak, tempat ibadah, angkutan umum, ruang kerja, serta tempat umum dan tempat lain yang ditunjuk.

\section{METODE PENELITIAN}

Penelitian ini mengggunakan metode kualitatif deskritif karena peneliti berusaha mendeskripsikan suatu kejadian, gejala, peristiwa yang terjadi dilapangan secara apadanya. Bodgan dan Taylor dalam Basrowi (2008;21) memaknai metode kualitatif ialah sebagai langkah maupun tahapan penelitian dan memperoleh data berbentuk deskriptif berbentuk data perilaku yang diamati, kata-kata lisan ataupun tertulis dari responden. Untuk teknik pengumpulan data peneliti memakai teknik wawancara, observasi serta dokumentasi. Berdasarkan judul peneliti oleh karena itu lokasi penelitian ini dilakukan di SMP Negeri 13 Kota Padang.Uji keabsahan data memakai trianggulasi dan analisis penelitian memakai reduksi data, penyajian dan verifikasi data.

\section{HASIL DAN PEMBAHASAN}

Dari penelitian dan kajian yang telah dilakukan dilapangan, Penerapan peraturan walikota Padang tentang kawasan tanpa rokok sudah terlaksana dengan baik. Berdasarkan teori George C. Edwar berpendapat, implementasi kebijakan dipengaruhi empat pariabel (Subarsono,2011;90-92):

\section{Komunikasi}

Komunikasi,adalah model penyampaian informasi secara langsung maupun tidak langsung oleh pemerintah kepada pihak sekolah kepada guru BK, staf guru, pegawai, siswa, penjaga kantin dan semua orang di lingkungan sekolah.

Implementasi kebijakan yang berhasil menuntut pelaksana memahami apa yang perlu dilakukan, dimana tujuan kebijakan perlu disampaikan kepada kelompok sasaran sehingga mengurangi sebaran implementasi.

Bersumber pada hasil penelitian yang sudah dilakukan di SMPN 13 Kota Padang sudah mengetahui mengenai paraturan kawasan tanpa rokok SMPN 13 kota Padang sudah menerapkan peraturan walikota Padang Nomor 25 tahun 2016tentang Pelaksanaan Peraturan KTR, Komunikasi yang dilakukan oleh pihak SMPN 13 Kota Padang yaitu dengan memasang rambu-rambu larangan merokok dan memasang himbuan-himbauan untuk tidak merokok. Komunikasi yang dilakukan 
bukan hanya dengan memasang ramburambu tetapi juga dilakukannya sosialisai dan selalu mengingatkan/ penyampaian pesan singkat pada setiap upacara bendera ataupun pertemuan-pertemuan.

Komunikasi dapat dinyatakan berhasil jika telah mencakup tiga indikator yaitu penyaluran, konsistensi, kejelasan komunikasi terpenuhi.

Transmisi, penyebaran komunikasi yang baik, dapat memanifestasikan satu penerapan yang menguntungkan.Seringkali terjadi hambatansaat penyaluran komunikasi diantaranya miskomunikasi.Banyaknya jenjang yang harus di lalui dalam sisitem komunikasi.Konsistensi komunikasi sangat dibutuhkan supaya kebijakan yang ditetapkan tidak simpang siur sehingga implementor, target group, dan satu pihak tidak bingung, harus jelas untuk ditetapkan dan dijelaskan.

Kejelasan, koneksi yang di dapat oleh pelaksana kebijakan harus jelas dan tak diragukan dan dapat memahami tentang maksud dan tujuan dan juga subtansi dari kebijakan. Memahami akan apa yang mesti disiapkan dan dilakukan untuk mengoptimalkan kebijakan secara efektif dan efisien.

\section{Sumberdaya}

Sumberdaya yang dimaksud adalah sumberdaya manusia, selain itu adanya anggaran dana serta fasilitas penunjang lainnya. Fasilitas yang dimaksud adalah rambu-rambu larangan merokok, poster dan lainnya yang menunjang penerapan KTR disekolah. Kendati isi peraturan ini telah diinformasikan secara jelas, akantetapi jikakurangnya sumber daya aturan yang di tetapkan tidak akan bekerja secara efektif. Sumberdaya manusia yang ada di SMPN 13 Kota Padang ini sudah memiliki jumlahyang cukup dalam mengiplementasikan peraturan walikota Padang tentang kawasan tanpa rokok, Dan jugasumberdaya fasilitas yang ada di SMPN 13 Kota Padang sudah memadai dalam menerapkan peraturan walikota
Padang tentang kawasan tanpa rokok.Seperti sudah memasang ramburambu larangan merokok.

Tidak menjadi persoalan seberapa jelas komunikasi dan kesesuaian penerapan dan seberapa teliti perintah tersebut disampaikan.Apabila personel yang bertanggung jawab untuk melakukan kebijakan kurang, maka hal yang dilakukanpun hasilnya kurangefektif.Sumberdaya ini mencakup empat komponen yang terdiri dari staf yang memadai, informasi yang di butuhkan untuk penetapan keputusan, kewenangan yang memadai guna menjalankan tanggung jawab serta fasilitas yang diperlukan dalam pelaksanaan.

Staf, merupakan kunci dalam penerapan kebijakan. Rusaknya pelaksanaankebijakan diantaranya dikarenakan oleh staf yang kurang mencukupi ataupun kurang memiliki keahlian.Informasi, dalam penerapan kebijakan memiliki dua informasi. Pertama, Informasi yang dapat berkaitan dengan cara menerapkan sebuah kebijakan. Implementor hendaklah mengerti dengan apa yang dikerjakansaat diperkenankan untuk melakukan aksinya. Kedua, perkara tentang ketaatan pelaksana regulasi pemerintah yang sudah di tentukan. Implementor hendaklah memahami apakah orang lain ikut dalam menerapkan kebijakan dan tunduk akan hukum. Wewenang, harus berkualitas agar instruksi dapat dilaksanakan secara efektif.Fasilitas, fasilitas fisik ialah faktor yang menentukan dalam penerapan kebijakan. Pelaksana kemungkinan memiliki staf yang cukup, mengatahuiapa yang mesti di lakukan, dan mempunyai kewenangan untuk melakukan kerjanya, dengan tidak adanya fasilitas yang mendukung seperti sarana dan prasarana maka implementasi itu tidak berhasil.

\section{Disposisi}

Disposisi yang dimaksud adanya dukungan, kemauan, keinginan dari seluruh pihak sekolah mulai dari kepala sekolah, wakil kepala sekolah, guru BK, Staf guru, pegawai, siswa, penjaga kantin dan semua 
masyarakat yang ada dilingkungan sekolah terhadap penerapan peraturan kawasan tanpa rokok sehingga kebijakan yang diterapkan dapat terlaksana sebagaimana mestinya.

Keberhasilan penerapan kebijakan bukan hanya dilihat sejauh mana implementor paham apa yang harus dilakukan serta mampu dalam menjalankannya. Selain itu keberhasilan suatu kebijakan juga berkaitan dengankemauan implementor dan mempunyai komitmen yang kuat terhadap kebijakan yang sedang di implementasikan.

Disposisi atau perilaku penyelenggara akan mengakibatkan kendala yang nyata mengenai penerapan kebijakan.Di SMPN 13 sudah berkomitmen dalam penerapan peraturan kawasan tanpa rokok megapa demikian karena aturan kawasan tanpa rokok yang ada di SMPN13 Kota Padang ini tidak hanya marak di permulaan saja meskipun sudah lama peraturan ini tetap diterapkan sebagaimana yang di informasikan.Disposisi merupakan faktor yang sangat diperlukan terhadap studi penerapan kebijakan publik. Sebagian pemangku kebijakan dapat menggunakan kewenangan dalam menerapkan peraturan. Apabila anggota yang ada takmenerapkan kebijakan yang dikehendaki. Oleh karena itu dalam memilih dan mengangkat personel kebijakan mesti orang-orang yang mempunyai dedikasi yang tinggi pada aturan-aturan yang diterapkan terkhusus yang berkaitan pada hajat orang banyak.

\section{Struktur Birokrasi}

Struktur birokrasi yaitu bertugas menerapkan kebijakan, yang mempunyai pengaruh signifikan terhadap pelaksanaan peraturan. Birokrasi ialah suatu badan yang selalu menjadi pelaksana kebijakan, baik secara sadar maupun tidak sadar memilih bentuk organisasi untuk mencapai persetujuan dalam rangka menyelesaikan kendala sosial pada kehidupan modern.Yang menjadi karakteristk birokrasi yaitu fragmentasi dan prosedur kerja.
Prosedur kerja atau Standar Operational Procedure(SOP) munurut Agustino (2014,153) SOP merupakan suatu pekerjaan dan barangkali dapat dilakukan kegiatan setiap harinya sesuai standar yang telah di tetapkan. SMPN 13 Kota Padang sudah memiliki SOP dalam menerapkan peraturan-peraturan yang berkaitan dengan lingkungan sekolah dan hal itu sudah terlaksana sebagaimana mestinya.Seperti adanya pihak yang dipercaya dalam mengawasi penerapan peraturan tentang KTR. Hal ini dibuktikan dengan adanya sanksi yang diberlakukan bagi oknum yang melakukan pelanggaran peraturan kawasan tanpa rokok di SMPN 13 Kota Padang. Dengan demikian dapat dikatakan bahwa aparat birokrasi dalam menerapkan peraturan daerah tentang kawasan tanpa rokok ini sudah dilaksanakan baik dari pihak kepala sekolah, guru, pegawai maupaun siswa yang ada di SMPN 13 Kota Padangsudah mentaati peraturan kawasan tanpa rokok.Sehinga peraturan kawasan tanpa rokok ini telah terlaksana sepenuhnya di SMPN 13 Kota Padang.

Fagmentasi, menurut (Agustino, 2014, p. 154) merupakan usaha persebaran tangung jawab kegiatan personel disebagian objek kerja.Tanggung jawab atas terlaksananya peraturan kawasan tanpa rokok ini perlu adanya kerja sama atara aparat birokrat, pegawai maupun siswa yang ada di lingkunganSMPN 13 Kota Padang. Dengan adanya keikutsertaan yang baik maka peraturan yang diterapkanpun dapat terlakasana dengan baik.

Dalam menjalankan sebuah kebijakan disuatu organisasi itu akan ada yang namanya kendala. Menurut Hansen dan Mowen mengelompokkkan kendala berdasarkan internal dan ekternal.

Kendala internal, kendala initernal merupakan faktor yang membatasi suatu organisasi dan merupakan sisitem yang berasal dari dalam organisasi.Adapun yang menjadi kendala internal dalam penerapan peraturan kawasan tanpa rokok di SMPN 13 Kota Padang adalah masih kurangnya pengawasan kepada sisiwa yang bolos 
Jayanti, Nora Eka Putril Penerapan Peraturan Walikota Padang Nomor 25 Tahun 2016 Tentang Kawasan Tanpa Rokok di SMP Negeri 13 Kota Padang

sekolah, sehingga dapat menyebabkan siswa merokok tanpa sepengetahuan guru yang ada di sekolah.

Kendala ekternal merupakan faktor yang membatasi organisasi yang berasal dari luar organisasi.Adapun yang menjadi kendala ekternal dalam penerapan kawasan tanpa rokoko di SMPN 13 Kota Padang disebabkan karena sekolah tersebut berada dilingkungan masyarakat.Jadi pengaruh untuk merokok dari masyarakat dapat dikatakan masih kuat.Adapun solusi dari permasalahan ini yaitu dengan meningkatkan pengawasan kepada siswa.

\section{PENUTUP}

Hasil penelitian dan pembahasan tentang penerapan peraturan walikota Padang nomor 25 tahun 2016 tentang KTR ialah sudah terlaksana dengan baik. Dari segi komunikasi yang dilakukan dalam penerapan peraturan kawasann tanpa rokok pihak sekolah sudah melakukan sosialisasi dan pemasangan rambu-rambu.Dari segi sumberdaya, sumberdaya yang ada dalm menerpkan peratran sudah memadai, baik dari segi sumber daya manusia, sumberdaya fasilitas dan sumberdaya keuangan.Dari segi disposisi pihak sekolah sudah melukan yang terbaik dalm menerapkan peraturan cntohnya dengan selalu mengingatkan untuk tidak merokok disetiap kegiatan sekolah.Dan dari segi struktur birokrasi juga sudah melakukan tugasnya dengan baik dalam penerapan peraturan kawasan tanpa rokok.

\section{DAFTAR KEPUSTAKAAN}

H., Akib, H., \& . H. (2016). Implementasi Kebijakan Program Makassar Tidak Rantasa (Mtr) Di Kota Makassar. Jurnal Ilmiah Ilmu Administrasi Publik. https://doi.org/10.26858/jiap.v6i2.247 7

Agustino, L. (2014). Dasar-Dasar Kebijakan Publik. CV.Alfabeta.

Arenawati. (2014). Administrasi
Pemerintah Daerah: Sejarah Konsep dan Pelaksanaan di Indonesia. Gava Media.

Dwiyanto, I. (2009). Kebijakan Public Berbasis Dynamic Polici Analysis. Gava Media.

Ndraha, T. (2003). Kybernology (Ilmu Pemerintahan Baru). Pt.Rineka Cipta.

Parson, W. (2001). Public Policy Pengantar Teori dan Praktik Analisis Kebijakan. Kencana Prenada Media Group.

Pasolog, H. (2007). Teori Administrasi Publik. Alfabeta.

Subarsono. (2011). Analisis Kebijakan Publik Konsep Teori dan Aplikasi. Pustaka Pelajar.

Wahab.S, A. (2013). Pengantar Analisis Implementassi Negara. Renika Cipta.

Winarno, B. (2012). Kebijakan publik, teori dan proses. Media Pressindo.

Yusuf, \& Switri, P. (2009). Modal Intelektual Dan Market Performance. Proceeding PESAT (Psikologi, Ekonomi, Sastra, Arsitektur \& Sipil) Universitas Gunadarma.

\section{Perundang-Undangan:}

Undaang-Undang Republik Indonesia nomor 36 tahun 2009 Pasal 115 ayat 1 dan 2 Tentang Kesehatan.

Peraturan Pemerintah Nomor 109 tahun 2012 Tentang Penanganan Bahan Yang Mengandung Bahan Adaptif.

Peraturan Bersama Menteri Kesahatan dan Menteri Dalam Negeri nomor 188 tahun 2011 dan nomor 7 tahun 2011 Tentang Pedoman Pelaksanaan Kawasan Tanpa Rokok.

Peraturan Walikota Padaang Nomor 25 Tahun 2016 Tentang Kawasan Tanpa Rokok. 